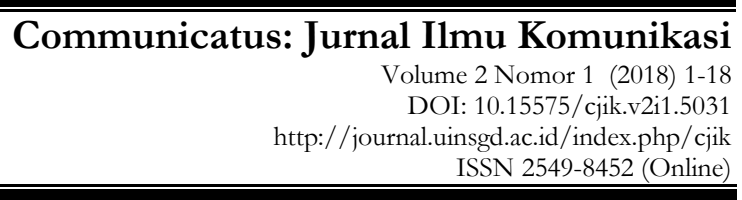

\title{
Komparasi Berita Tenaga Kerja Indonesia di Arab Saudi dalam Detikcom dan Sabq.Org
}

\author{
Muhamad Fahrudin Yusuf ${ }^{*}$, Mukti Ali ${ }^{2}$ \\ ${ }^{12}$ Instutu Agama Islam Negeri, Salatiga \\ *email: mfakhrys@gmail.com
}

\begin{abstract}
ASBTRACT
$V$ arious problems of migrant workers and their alleged different coverage on various media are the background of this research. This study focused on 131 news items on migrant workers' issues in Saudi Arabia in the online newspapers Detikcom and Sabq.org, with details of Detikcom 64 news and Sabq.org 67 as samples, with the aim of finding out how Detikcom and Sabq.org cover Indonesian migrant workers in Saudi Arabia and the difference in coverage of both. The content analysis method was chosen as an analysis tool with Codingsheet as a data collection technique and chi-square as a different test tool. The findings of this study are that there is uniformity of coverage on news about migrant workers in Saudi Arabia at Detikcom and Sabq.org with several categories of significant differences.
\end{abstract}

Key Words: Comparison of TKI news, Detikcom and Sabq.org, SKE.

\begin{abstract}
ABSTRAK
Berbagai permasalahan TKI dan peliputannya yang diduga berbeda pada berbagai media melatarbelakangi penelitian ini. Penelitian ini difokuskan pada 131 isi berita permasalahan TKI di Arab Saudi pada suratkabar online Detikcom dan Sabq.org, dengan perincian Detikcom 64 berita dan Sabq.org 67 berita sebagai sampel, dengan tujuan untuk mengetahui bagaimana Detikcom dan Sabq.org meliput TKI di Arab Saudi dan perbedaan liputan keduanya. Metode analisis isi dipilih sebagai alat analisis dengan codingsheet sebagai teknik pengumpulan data dan chi-square sebagai alat uji beda. Temuan dari penelitian ini adalah bahwa ada keseragaman liputan pada berita tentang di TKI di Arab Saudi pada Detikcom dan Sabq.org dengan beberapa kategori didapati perbedaan signifikan.
\end{abstract}

Kata Kunci: Komparasi berita TKI, Detikcom dan Sabq.org, SKE.

\section{PENDAHULUAN}

Seleksi atas unsur di dalam berbagai elemen berita mencirikan isi berita. Salah satunya berita pada realitas TKI di Arab Saudi. Bagi sebagian orang, isi berita adalah realitas sosial itu sendiri. Sementara bagi yang lain isi berita hanyalah satu bentuk realitas dari sebagian realitas yang sebenarnya. Penelitian ini ingin 
mengobservasi dan membandingkan isi berita tentang TKI di Arab Saudi pada suratkabar online Detikcom dan Sabq.org.

Menurut laporan BN2PTKI terdapat 15 permasalahan (kasus) yang menimpa TKI pada periode Januari hingga April 2008. Antara lain: gaji tidak dibayar, penganiayaan, pelecehan seksual, majikan meninggal, pekerjaaan tidak sesuai PK, PT bermasalah, putus komunikasi, PHK, pemutusan sepihak, kecelakaan kerja, sakit akibat kecelakaan kerja, sakit biasa, meninggal, kriminal, gagal berangkat (Sumber: bnp2tki go.id). Kasus mutakhir yang terjadi adalah dieksekusinya TKI Tuti Tursilawati pada 29 Oktober 2018 TKI tanpa ada notifikasi dari pemerintah Saudi (Detikcom 2 November 2018).

Realitas yang demikian itu jelas benilai berita bagi media di kedua negara. Salah satunya dari majalah Hidayatullah.com (10-11-2010) mengutip data resmi dari KBRI Arab Saudi dan KBRI Kuwait bahwa sebanyak 3.627 orang TKI yang mencari perlindungan dari tindak kekerasan fisik dan seksual ke KBRI. Media cetak Kompas edisi 1 Desember 2011 menyebutkan bahwa Pada tahun 2011 tercatat 862 TKI bermasalah dipulangkan dari Arab Saudi. Di lain pihak, suratkabar online Arab Saudi yaitu Sabq.go.id (06-12-2011) mengabarkan kerugian akibat tindakan melarikan diri para TKI mencapai 45 juta riyal atau 1,2 miliar rupiah pertahun. Data ini menggambarkan bahwa banyak TKI yang melarikan diri dari pekerjaan dan mengakibatkan kerugian yang besar bagi penggunanya.

Pemberitaan yang nampak memiliki sudut pandang berbeda ini menjadi menarik untuk diteliti. Berdasarkan penelusuran sementara peneliti dalam sepuluh tahun terakhir pemberitaan tentang TKI di paling banyak dapati pada tahun 2011.

Pemberitaan dalam surat kabar elektronik (SKE) terutama dengan mengambil objek detik.com sering dilakukan. Akan tetapi, dengan mengambil objek penelitian terkait Tenaga Kerja Indonesia tidak terlalu banyak dilakukan. Beberapa penelitian yang memiliki relevansi dengan penelitian ini antara lain, penelitian tentang komparasi nilai berita dalam tayangan televisi (Sari, 2015) berkaitan dengan perbandingan nilai berita dalam perspektif jurnalistik dalam tayangan televisi dengan mengambil kasus tayangan insert. Penelitian tentang Human Trafficking dalam berita Surat Kabar Elektronik (SKE) di lima negara di kawasan ASEAN (Astrid, 2011). Penelitian tentang analisis isi berita dalam opini berita Surat Kabar Elektronik (SKE) lampung post (Handayani, 2011). Penelitian tentang analisis isi berita dalam surat kabar (Ramli, 2015), penelitian ini mengambil isu demonstrasi. Serta penelitian dengan mengambil kasus detik.com berkaitan dengan kaidah jurnalistik (Hardi, 2015).

Penelitian tentang pembingkaian berita online pada media serambinews.com dan panjimas.com (Rubawati, 2018). Penelitian ini mengambil fokus pada pembingkaian berita tentang LGBT. Berita online dimaknai sebagai 
Komparasi Berita Tenaga Kerja Indonesia di Arab Saudi dalam Detikcom dan Sabq.Org instrumen dakwah kontemporer yang dapat menyebarkan risalah Islam. Penelitian lainnya tentang pelanggaran HAM pada korban Mesuji Lampung (Nurcahyo, 2013). Penelitian ini berkaitan dengan konstruksi berita HAM yang dimuat pada harian Kompas. Penelitian menggunakan analisis framing. Penelitian berkaitan dengan pemberitaan kasus asusila anak dengan mengkomparasikan antara media online detik.com dan merdeka.com (Ajeng, 2014). Penelitian tentang pembingkaian berita pada media online berkaitan dengan Tenaga Kerja Wanita (Akbarian, Suprihatini, Yulianto \& Nugroho, 2014). Penelitian ini mencoba menganalisis bagaimana konsruksi TKW direpresentasikan dalam media online. Penelitian tentang opini pemberitaan Kebakaran Hutan (Utami, 2017). Penelitian ini mengkomparasikan pemberitaan kebakaran hutan melalui sistem algoritma biner. Penelitian dilakukan sebagai upaya menganalisis bagaimana bingkai berita yang dimuat dalam media online. Penelitian tentang pemasaran brand value melalui pembingkaian berita tentang haji pada harian Post Kota dan Rakyat Merdeka (Marta \& Septyana, 2015). Penelitian ini menganalisis pembingkaian berita melalui layout berita haji dengan mengkomparasikan dua media yang berbeda.

Adapun penelitian yang mengambil objek kajian tentang Tenaga Kerja Indonesia (TKI) antara lain, penelitian tentang pemanfaatan teknologi informasi dan komunikasi oleh TKI dalam meningkatkan perubahan sosial (Amalia \& Rachmawati, 2013). Penelitian ini mengambil studi kasus di Kampung Pandan Dalam, Malaysia. Penelitian mencoba meneropong bagaimana keterampilan dalam pemanfaan teknologi informasi dapat meningkatkan kemampuan dan apresiasi terhadap TKI. Penelitian tentang konstruksi Tenaga Kerja Wanita (TKW) berkaitan dengan profil kemampuan dan motivasinya dalam bekerja (Geriya, 2002). Penelitian tentang penawaran dan permintaan terhadap TKI berkaitan dengan peningkatan upah kerjanya (Sholeh, 2007). Serta penelitian tentang analisis produktifitas TKI dan pertumbuhan ekonomi Indonesia (Ramayani, Aimon \& Anis, 2012).

Beberapa penelitian memiliki perbedaan dengan penelitian ini, terutama berkaitan dengan objek dan focus permasalahan. Penelitian dengan mengambil objek detik.com dan metode analisis isi berita sudah banyak dilakukan, perbedaan dengan penelitian ini terutama berkaitan dengan isu pemberitaan tentang Tenaga Kerja Indonesia (TKI) dan komparasi dengan surat kabar elektronik Sabq.org.

Pada tahun 2011 didapati lebih dari 60 berita terkait TKI pada media online Indonesia, Detikcom. Jumlah yang mendekati sama, lebih dari 60 berita juga didapati pada media online di Arab Saudi Sabq.org. Kedua media online ini pada tahun 2011 berada pada peringkat pertama media online paling populer menurut salah satu situs pemeringkat di internet, alexa.com (27 September, 2011). 
Pada akhirnya muncul persoalan bagaimana TKI di Arab Saudi diberitakan oleh Detikcom dan Sabq.org dan bagaimana perbedaan liputan tentang TKI di Arab Saudi oleh Detikcom dan Sabq.org.

\section{HASIL DAN PEMBAHASAN}

\section{Berita di Surat Kabar Online}

Proses produksi berita online hingga dapat dinikmati tidak jauh berbeda dengan produksi berita cetak. Proses produksi berita online dimulai dengan: 1). Pengumpulan dan pemilahan fakta, 2). Pengolahan fakta, 3). Penyajian Berita. Untuk lebih dapat dipahami mengenai kinerja dan proses produksi berita tersebut, diperlukan pemaparan yang lebih luas baik secara teoritis maupun praksis, sebagai berikut; Pertama, pengumpulan fakta dalam jurnalisme online, seperti dijelaskan Stephen Quinn dan Stephen Lamble (2008: 50), secara fundamental melalui berbagai proses, dimulai dari ide dari jurnalis, dilanjutkan dengan pengembangan berita melalui wawancara, online research, dan dokumen dari beberapa sumber berita, selanjutnya cerita itu ditulis menjadi berita. Berita dapat digali dan diperoleh dari sumber berita manusia, tempat dan peristiwa. Sumber berita sendiri merupakan tempat atau orang yang berita dapat digali melalui wawancara karena posisinya atau karena apa yang dia katakan (McKane, 2006: 16). Bahkan internet sendiri merupakan sumber informasi terbesar (Quinn dan Lamble, 2008: 1).

Dari jutaan peristiwa yang terjadi setiap hari tidak semuanya bernilai dan layak menjadi berita. Mike Ward (2002: 31) menyatakan bahan baku berita dalam jurnalisme online adalah sama dengan apa yang tersaji dalam media konvensional, yaitu fakta. Perubahan definisi berita dalam jurnalisme online juga tidak merubah konsep nilai berita tradisional yang menjadi ukuran kualitas pemberitaan. Sampai-sampai Carole Rich (2010: 12) menyatakan "definitions of news are changing. But these are some traditional qualities of news stories". Pada masa lalu berita mungkin dapat didefinisikan sebagai laporan tentang fakta atau ide terkini, yang dipilih staf redaksi suatu harian untuk disiarkan, yang dapat menarik perhatian pembaca, entah karena luar biasa, pentingnya atau akibatnya, entah pula karena mencakup segi human interest seperti humor, emosi dan ketegangan (Assegaf, 1983: 24).

Dalam jurnalisme online berita diartikan dengan lebih luas sebagai multimedia, instan, global dan ada di mana-mana (Hargreaves, 2005: 131). Sehingga secara definitif memang terjadi perubahan dalam pengertian berita, namun tidak dalam nilai berita. Nilai berita dimaksud adalah: Pertama, ketepatan waktu atau timelines pemberitaan. Dalam media online, ketepatan waktu merupakan kesegeraan (immediacy) dan bahkan lebih penting; Kedua, terkait dengan kedekatan geografis dan kedekatan emosional (proximity) pembaca. Suatu peristiwa menarik bagi pembaca lokal karena hal itu terjadi atau dekat dengan 
Komparasi Berita Tenaga Kerja Indonesia di Arab Saudi dalam Detikcom dan Sabq.Org masyarakat; Ketiga, merujuk pada ternama tidaknya (importance) orang yang diberitakan. Johan Galtung dan Mari Ruge (dalam McKane, 2006: 8) menyebut kategori nilai berita ini sebagai elite people, atau mereka yang pada hari ini disebut dengan selebritis. Keempat,: sifat keluarbiasaan, aneh, ajaib, atau jarang terjadi (unusual nature), yang muncul dari peristiwa atau seseorang; Kelima, konflik atau kontrovesial (conflict/controvercy) yang terlihat dalam berita. Dalam hal ini termasuk di dalamnya konflik aktual, konflik politik, kriminal, bencana alam dan kecelakaan (McKane, 2006: 7); Keenam, merujuk pada relevansi berita dengan pembaca (buman interest) atau terjadi pada orang biasa yang bukan selebriti (McKane, 2006: 11); Ketujuh, dampak (impact) yang muncul dari pemberitaan atau sudut pemberitaan dari suatu peristiwa yang besar dan berskala nasional atau internasional; Kedelapan, tips yang bermanfaat bagi konsumen (belpfulness), seperti tips tentang kesehatan; Kesembilan, berita menghibur (intertainment) bagi khalayak; Kesepuluh, nilai berita ini biasanya terkait dengan nilai konflik dan kedekatan (issues or problems in the community); Kesebelas, yang berkait dengan isu yang berkembang dan meningkat pada waktu tertentu (trend).Seperti isu meningkatnya kriminalitas (Rich, 2010: 12).

Kedua, Pengolahan fakta merupakan salah satu proses produksi berita. Transisi dari jurnalisme elektronik dan cetak menuju jurnalisme online tentu membawa berbagai implikasi penting. Termasuk pada praktik jurnalisme online (Gunter, 2003: 56). Namun demikian ada hal yang penting yang tidak berubah.

Mike Ward (2002: 103) menyatakan keterampilan menulis berita tetap menjadi prinsip utama dalam jurnalisme online. Begitu juga dengan prinsip ekonomis dalam penulisan dengan bahasa lugas, karena space yang terbatas. Hal ini diperkuat dengan pernyataan Barry Gunter (2003: 56) bahwa perubahan dalam jurnalisme online tidak merubah kepada kebutuhan akan kemampuan (skill) dalam pelaporan berita.

Penulisan berita pada umumnya menggunakan struktur piramida. Ward (2002: 111) menyatakan bahwa teknik cerita dalam berita online dapat menggunakan stuktur piramida maupun piramida terbalik.

Pada struktur piramida menurut Ward didapati dua keuntungan, antara lain, pertama, pembaca dapat membaca inti cerita hanya dengan membaca pendahuluannya saja. Kedua, sub-editor surat kabar online dapat menghemat waktu dan space dengan memotong cerita tanpa merusak pengetahuan pembaca pada cerita di dalam berita itu.

Selain kemampuan menulis yang baik, Barry Gunter (2003: 56) menambahkan perlunya perangkat praktis bagi wartawan dalam pelaporan berita dalam jurnalisme online.

Mengingat berita dalam jurnalisme online bukan hanya terdiri dari teks berita, namun gabungan dari beberapa media seperti video (audio visual), dan foto dalam format digital yang telah tersedia diberbagai situs (instan) dan bersifat 
global dan ada dimana-mana. Sehingga informasi berita dalam jurnalisme online termasuk kategori informasi superhighway (Pavlik, 1996: 405).

Secara lebih lugas Carole Rich (2010: 61) menjelaskan bahwa basis dasar berita jurnalisme online sama dengan surat kabar cetak, yaitu fakta dengan prinsip immediasi (kesiapan) tetap menjadi maint point penulisan berita (Rich, 2010: 60). Namun demikian, sajian berita dalam jurnalisme online tidak memandang kelengkapan berita sebagai sebuah keharusan. Kate Marymont, executive editor of The News-Press Florida AS (dalam Rich, 2010: 67) di selasela waktu istirahat dalam sebuah pelatihan produksi berita online memposting berita tentang suatu isu tanpa harus melengkapinya. Dia menjelaskan pentingnya kecepatan sebagai kelebihan dari jurnalisme online. Tenggat waktu itu digunakan untuk memverifikasi berita yang sedang diposting. Dengan demikian dapat diketahui kecepatan menjadi faktor utama sajian berita dalam jurnalisme online.

Ketiga, secara garis besar berita dalam jurnalisme online dapat disajikan dalam format hardnews dan softnews. Sementara format feature merupakan bagian dari softnews (Rich, 2010: 17). Hardnews adalah cerita yang bersifat tepat waktu tentang peristiwa atau konflik yang baru saja terjadi atau akan terjadi, seperti kejahatan, kebakaran, pertemuan, demonstrasi, pidato dan kesaksian dalam kasus-kasus di pengadilan (Rich, 2010: 17). Pendekatan hardnews pada dasarnya adalah penjelasan tentang apa yang terjadi, mengapa hal itu terjadi dan bagaimana pembaca akan terpengaruh oleh berita itu.

Softnews didefinisikan sebagai berita yang menghibur atau informatif dengan penekanan pada kemanusiaan, dengan unsur kebaruan dan kedekatan yang lebih rendah daripada hardnews. Feature merupakan bagian dari softnews yang terfokus pada orang dan tempat tertentu, atau cerita yang mempengaruhi kehidupan pembaca (Rich, 2010: 17).

Dalam format hardnews dan softnews dalam jurnalisme online, berita ditulis dengan struktur piramida (Ward, 2002: 111). Khusus untuk format softnews dimungkinkan tidak selalu mengunakan struktur piramida terbalik (Abrar, 2005: 9). Dengan struktur yang sedemikian itu bagian atas menjadi bagian terpenting. Semakin ke bawah berita menjadi semakin tidak penting. Oleh karena itu lead (paragraf pertama) memiliki peranan penting dalam berita. Lead merupakan awal cerita yang dapat menarik perhatian pembaca, dan bagian terpenting dalam berita (Abrar, 2005:7). Begitu pentingnya posisi lead hingga banyak penulis khawatir tentang apa yang harus ditulis pertama dalam sebuah tulisan (Rich, 2010: 131).

Sebagai ikhtisar berita lead biasanya memuat jawaban dari salah satu pertanyaan what, who, when, who, where, why, dan how atau dikenal dengan prinsip 5 W+1 H. Namun karena fungsinya sebagai ringkasan berita, dan karena space yang terbatas kelima unsur tidak terpenuhi dalam lead berita online. Selain lead, judul (headline) memiliki peranan penting, karena dalam berita mata adalah 
Komparasi Berita Tenaga Kerja Indonesia di Arab Saudi dalam Detikcom dan Sabq.Org "penyantap" pertama hidangan informasi, dan santapan yang paling menarik adalah judul.

Rich (2010: 8) menyatakan karakteristik berita online meliputi: Continual deadline yang menunjukkan tidak ada deadline berita. Interactive content; pembaca dapat berinteraksi secara langsung dengan jurnalis dan editor. Related linked; link terkait berita yang disajikan, termasuk link sumber berita. Nonlinier struktur; pembaca dapat memilih berita yang disajikan tanpa harus mengikuti struktur linier yang biasa terdapat dalam media konvensional. Database; informasi yang bermanfaat bagi pembaca. Personalized journalism; situs berita online selain Blog yang menyediakan space bagi pembaca untuk berbagi cerita dan gambar. Specialized beats; tawaran berita yang lebih menyeluruh dari berbagai dimensi kehidupan, tidak terbatas pada dimensi khusus, seperti politik atau kesehatan.

Secara empiris produksi berita online dapat dilihat dari berbagai hasil penelitian akademik yang telah dilakukan. Salah satunya adalah penelitian setingkat tesis yang dilakukan Anshori (2010) dari Universitas Sebelas Maret (UNS) Surakarta, praktik jurnalisme online pada surat kabar elektronik sebelum ada pedoman dari Dewan Pers dapat dilihat pada temuan penelitian yang dilakukan oleh Anshori (2010) pada kompas.com.

Menurut salah seorang wartawan kompas.com, Tri Mulyono (2010) pada dasarnya kompas.com dalam memproduksi berita memiliki alur dan struktur berita yang sama, mulai dari reporter, editor sampai dengan pemimpin redaksi. Perbedaan yang paling menonjol adalah pada faktor kecepatan menyampaikan berita, antara media online yang bersifat 'real time', yakni suatu peristiwa dapat dilaporkan seketika.

Sifat real time ini bukan berarti fungsi editing dan pertimbanganpertimbangan editorial lainnya dihilangkan sama sekali. Terkait dengan ciri berita, Tri Mulyono menyatakan bahwa jika media online fokus pada bagaimana dan apa peristiwa yang sedang terjadi. Prioritas kompas.com adalah berita-berita yang menarik dan cenderung bombastis, baru kemudian berita penting dan analisis.

Sementara pada Detikcom bahwa konsepsi berita Detikcom cenderung menekankan aspek kecepatan. Detikcom hanya melaporkan berita yang didapat dari proses liputan, menginformasikan masyarakat Indonesia tentang apa yang sedang terjadi di Indonesia dan di dunia.

Detikcom tidak membuat headline (berita utama) untuk liputan, karena yang menjadi headline adalah yang tercepat masuk ke desk redaksi. Dengan kata lain, headline karena pertimbangan-pertimbangan editorial dikesampingkan dan diserahkan sepenuhnya kepada pembacanya untuk memilih mana yang menjadi berita penting dan tidak.

Konsep aktualitas dan kebaruan ini menurut Fajar Widiantoro (dalam 
Anshori, 2010) dari desk teknologi Detikcom tidak ada perbedaan dengan dua media pendahulunya (cetak dan penyiaran). Produksi berita melalui proses gathering-editing-publishing.

Proses produksi berita pada Detikcom menganut prinsip pencarian, editing dan penyajian berita sepertihalnya media-media massa pada umumnya, namun yang dititiktekankan pada "naik saat itu juga", prinsip kecepatan sebuah berita.

Dalam kaitannya dengan interaktifitas yang secara teoritis selama ini dianggap fitur terpenting internet dapat dilihat dari penelitian yang dilakukan oleh Chang (dalam Severin dan Tankard, 2009: 454) pada tahun 1998 pada mahasiswa melalui kuesioner yang dikirim melalui email.

Hasil penelitian itu menyatakan bahwa alasan mereka memanfaatkan berita online lebih kepada sifat media baru, yaitu kesiapan (mengetahui sesuatu dengan segera) dan stabilitas (mendapatkan berita kapan saja mereka inginkan) yang dimiliki media baru. Khalayak lebih membutuhkan kecepatan daripada cerita dari berita itu sendiri.

Dengan demikian dikaitkan dengan isi berita secara prinsipil tidak ada perubahan dalam praktik jurnalisme online. Isi berita tetaplah realitas sosial atau fakta yang dikonstruksi. Sehingga secara teoritis peneliti berasumsi produk jurnalisme online tetaplah sama dengan jurnalisme konvensional yang dipengaruhi oleh seleksi atas fakta dan sumber.

Perbedaan hanya dari sisi tampilan grafis dan perfomansi dalam bentuk digital (HTML) yang tentunya tidak mempengaruhi terhadap isi berita. Kebutuhan teoritis atas jurnalisme online tercukupi dengan teori dasar jurnalisme cetak dan siaran.

Di sisi lain perbedaan sistem media sebagai konteks jurnalisme biasanya menghasilkan praktik jurnalisme yang berbeda. Media di negara yang memiliki paralelisme politik tinggi dengan pemerintah atau cenderung otoriter secara ekonomi termarginalkan dan membutuhkan subsidi.

Pada saat subsidi datang dari pemerintah penguasa memperalat pers untuk menyampaikan informasi yang menguntungkan penguasa. Hal ini menjadi gambaran umum nasib media di Arab Saudi.

Di Arab Saudi kontrol atas pers dimulai pada tahun 1970an (Sakr dalam De Hugo (ed.), 2005: 142). Dengan kata lain penguasa tidak memberi kesempatan kepada pers untuk menyampaikan kehendak masyarakat. Adalah wajar kalau pers menjadi milik penguasa (Siebert, 1986: 11).

Sebaliknya dalam sistem pers yang demokratis organisasi dan isi media tidak tunduk pada pengendalian politik dan pemerintah. Warga negara secara individu atau berkelompok minoritas memiliki hak untuk memanfaatkan media dan hak untuk dilayani media sesuai dengan kebutuhan mereka (McQuail, 1994:131).

Sistem ini menegaskan bahwa tidak ada pihak yang mendominasi aktifitas, 
Komparasi Berita Tenaga Kerja Indonesia di Arab Saudi dalam Detikcom dan Sabq.Org tugas, dan fungsi pers. Semua pihak berhak untuk mendirikan pers sesuai dengan nilai-nilai yang mereka anut. Mereka tidak perlu mendapatkan izin dari pemerintah. Sistem inilah yang dianut pers Indonesia sejak Indonesia dipimpin oleh K.H. Abdurrahman Wahid hingga sekarang (Abrar, 2011; 51).

Dalam praktiknya seleksi atas fakta dan sumber berita akan berbeda dalam sistem media yang demokratis dan sistem yang cenderung otoritarian.

Temuan empiris Hallin dan Mancini (2005:73) pada media di Prancis, Yunani, Portugal dan Spanyol yang cenderung otorian menyatakan bahwa tradisi jurnalisme jurnalisme komentar atau advokasi menjadi dominan di negara dengan sistem media authoritarian dibanding jurnalisme laporan.

Fakta dan sumber berita yang mendukung atau tidak merugikan pemerintah cenderung menjadi pilihan. Demikian halnya media di TimurTengah, khususnya Arab Saudi, temuan empiris William A. Rugh (2004: 59) dalam studi klasiknya pada tahun 1970 dengan membandingkannya dengan media di tahun 1900-1950an. Rugh memasukkan media di Arab Saudi dalam tipologi loyalis kepada pemerintah.

Komparasi dalam sebuah pemberitaan media massa sangat erat kaitannya dengan ekonomi-politik media. Pada perspektif ini, komparasi berita dapat dilihat secara kritis dari berbagai kepentingan, baik kepentingan ekonomi, politik dan kepentingan ideologis dari para pengelola media. Dalam perkembangan kebudayaan manusia, komunikasi massa menjadi proses komunikasi yang mempunyai tingkat pengaruh yang cukup signifikan pada kehidupan sehari-hari. Berita, dalam konteks komunikasi massa yang berkembang sampai sekarang, selalu muncul dalam benak dan pikiran manusia. Berita yang disusun dalam benak manusia bukan merupakan peristiwa manusia (Syuderajat, 2017: 4-5).

Berdasarkan diskusi teoritis dan berbagai temuan di atas sistem media yang berbeda cenderung menghasilkan isi berita yang berbeda. Meskipun secara jurnalisme isi berita tetaplah konstruksi dari realitas sosial.

\section{Berita Tentang Tenaga Kerja Indonesia (TKI) di Arab Saudi}

Berita merupakan fakta terkini dan bernilai informasi bagi khalayak. Menjadi pengetahuan yang jamak bahwa basis berita adalah realitas sosial. Termasuk di dalamnya adalah fakta tentang TKI di Arab Saudi. Fakta tentang TKI umumnya merujuk pada berbagai persoalan menyangkut TKI di tempat kerja atau luar negeri. Karena permasalahan lebih sering terjadi di tempat kerja/di luar negeri (Sahayu dalam Sastriani (ed.), 2008: 688). Meskipun 85\% permasalahan yang terjadi pada TKI adalah limbah dari persoalan yang terjadi di dalam negeri (Sutedi, 2009: 247).

Secara umum menurut laporan BN2PTKI terdapat 15 permasalahan (kasus) yang menimpa TKI pada periode Januari hingga April 2008. Antara lain: gaji tidak dibayar, penganiayaan, pelecehan seksual, majikan meninggal, pekerjaaan tidak sesuai PK, PT bermasalah, putus komunikasi, PHK, pemutusan 
sepihak, kecelakaan kerja, sakit akibat kecelakaan kerja, sakit biasa, meninggal, kriminal, gagal berangkat (Sumber: bnp2tki go.id)

Di sisi lain tidak semua permasalahan yang terjadi mendapat porsi pemberitaan. Hal ini bisa dimaklumi mengingat tidak semua fakta memenuhi standar newswortbiness dan layak berita. Peran gatekeeper dalam organisasi media sangat menentukan dalam seleksi berita dan penyajian berita. Berita yang sesuai dengan nilai yang dianut oleh suatu organisasi media sepanjang tidak merugikan media itu sendiri tentu akan dirilis.

Dari sekian banyak persoalan yang terjadi, besar dugaan kekerasan dan kriminalitas menjadi isu besar yang secara teknis bernilai berita tinggi. Asumsi itu diperkuat dengan adanya data yang menyebutkan bahwa TKI di Arab Saudi menjadi impotir persoalan kekerasan terbesar bagi negara dibanding TKI di negara tujuan TKI lainnya.

Menurut data Migrant Care, kekerasan terhadap TKW di Arab Saudi menempati tempat teratas dibanding kekerasan negara tujuan TKW lainnya, yakni 48 persen (metronews.fajar.co.id. 25/10/2011). Data tersebut diperkuat lagi oleh berbagai hasil penelitian yang relevan dengan isu kekerasan terhadap TKI.

Di antaranya adalah penelitian yang dilakukan oleh Rahayu (dalam Sastriani, ed., 2008: 685) dari Pusat Studi Wanita UGM pada tahun 2008. Hasil temuan terkait kekerasan yang dialami oleh para TKW sektor domestik atau PRT adalah kekerasan fisik, kekerasan psikologis, kekerasan seksual, kekerasan ekonomi, dan perampasan kemerdekaan secara sewenang-wenang.

Penelitian serupa dilakukan oleh Sutaat pada tahun 2006. Kekerasan yang sering menimpa TKW menurut penelitian yang termuat dalam Jurnal Penelitian dan Pengembangan Usaba Kesejabteraan Sosial, Vol 11, No. 03, (2006: 55) adalah tekanan mental dan fisik. Di antaranya adalah perlakuan sebagian majikan yang kurang manusiawi, tindak kekerasan, dan pelecehan seks/perkosaan.

Di samping itu nilai berita bernilai konflik nampak pada dampak sosialpolitik permasalahan TKI. Penelitian IOM pada tahun 2010 terkait buruh migran dibeberapa negara. Salah satunya di Singapura. Kasus-kasus yang berdampak sosio-politis yang signifikan bagi hubungan Indonesia dan Singapura adalah pembunuhan, perlakuan kejam, perkosaan yang diikuti oleh penyiksaan dan kematian.

Dengan demikian nilai konflik dan kontroversi diduga menghiasi berita tentang TKI di Arab Saudi. Konflik sendiri merupakan informasi yang menggambarkan pertentangan antar manusia, bangsa dan negara yang perlu dilaporkan kepada khalayak agar mereka dapat mengambil sikap (Abrar, 2005:4).

Dennis McQuail (1994: 162) menjelaskan bahwa seleksi atas berita (isi dan proses penyajian) merupakan subyektifitas yang dipengaruhi oleh beberapa faktor, antara lain, faktor manusia, lokasi, dan waktu. Biasanya faktor-faktor 
tersebut membentuk kombinasi.

Faktor manusia dapat diidentifikasi dari sumber berita, sehingga seringkali berita merupakan apa yang dikatakan oleh tokoh tertentu, bukan peristiwa laporan itu sendiri. Faktor lokasi mempengaruhi seleksi setelah terlebih dahulu dilakukan observasi oleh wartawan atas suatu isu. Tempat Kejadian Perkara (TKP) dan tempat penyebaran berita seperti pengadilan, kantor polisi, parlemen, bandara, rumah sakit dan lain sebagainya menjadi pilihan lokasi berita. Faktor waktu terkait determinasi atas nilai terkini berita dalam format hardnews. Faktor lainnya adalah kedekatan dengan sasaran berita (audiens), isi berdasar pada prioritas dan memiliki resiko kecil pada organisasi media.

Secara empiris Nunung Prajarto dkk., dalam penelitiannya mengenai berita pembangunan di kabupaten Sleman tahun 2006, dengan mengutip dari berbagai sumber, menyatakan sumber berita yang digunakan suratkabar saat meliput suatu peristiwa bisa jadi bermacam-macam.

Empat tipe dasar sumber berita biasanya dipakai untuk mengidentifikasi sumber berita, meskipun sumber berita yang paling sering diterapkan oleh institusi suratkabar merupakan gabungan atau kombinasi keempat bentuk dasar itu. Keempat bentuk sumber berita itu adalah sumber berita formal (dari unsur pemerintah), laporan tangan pertama (wartawan dan saksi peristiwa), sumber berita dari pihak non-formal (perusahaan atau pihak bukan unsur pemerintah) dan leak atau bocoran.

Terkait dengan tipe koverasi dari sumber berita suatu item berita bisa ditampilkan dengan koverasi satu sisi (one-sided coverage) dan dua atau banyak sisi (two-sided or multi-sided coverage) (McQuail, 1992: 224-234). Prajarto dkk dalam penelitian yang sama menyatakan tipe koverasi ini biasanya dikaitkan dengan masalah keberimbangan berita serta masalah fairness. One-sided coverage biasanya melaporkan peristiwa yang tidak mengandung konflik.

Dalam hal ini semua sumber berita berasal dari satu kelompok atau satu pandangan tertentu.

Two or multi-sided coverage biasanya diterapkan pada sumber berita yang mewakili dua pandangan yang berbeda. Hanya saja koverasi satu sisi masih dimungkinkan bila peristiwa yang diliput memang tidak mengandung suatu konflik.

Sementara penyajian isi berita biasanya bercirikan tujuan, arah, atau kecenderungan tertentu (McQuail, 1994: 175). Hal ini biasanya terkait dengan kebijakan redaksional masing-masing organisasi media. Sehingga pada titik ini berita berita dipandang memiliki tujuan. Dari performansi atau penggambaran ini penilaian terhadap media dan organisasi media dapat dilacak.

Penelitian akademik setingkat tesis yang dilakukan oleh Mulyono (2011) dari Universitas Gadjah Mada Yogyakarta tentang berita kekerasan terhadap anak dalam suratkabar elektronik (SKE) dengan membandingkan mendapati 
menunjukkan bahwa format berita straight news (hardnews) dan soft news banyak digunakan oleh SKE Detikcom dan Okezone dalam menyiarkan berita kekerasan terhadap anak dalam suratkabar elektronik (SKE).

Sementara nilai berita yang ditonjolkan terdapat perbedaan nilai berita dominan dalam nilai berita kombinasi yang ditonjolkan oleh Ske Detikcom dan SKE Okezone.com. SKE Detikcom, menonjolkan nilai berita timelines, importance dan prominence, sedangkan SKE Okezone.com lebih ditonjolkan nilai berita buman interest, conflict/controversy, dan prominence.

LSM menjadi sumber berita yang dominan dalam pemberitaan tentang kekerasan terhadap anak yang dilakukan oleh SKE Detikcom, sedangkan SKE Okezone.com lebih mengandalkan aparat pemerintah sebagai sumber berita utama dalam pemberitaan kasus kekerasan terhadap anak. Tipe peliputan dua sisi sama-sama lebih banyak digunakan oleh dalam mem SKE Detikcom maupun SKE Okezone.com buat berita tentang kekerasan terhadap anak.

Berdasarkan diskusi di atas liputan berita di SKE kemungkinan terdapat kesamaan antara media di Indonesia dan Arab Saudi dalam dominasi format hardnews. Seperti diketahui hardnews menjadi format pilihan untuk berita yang secepatnya harus diketahui khalayak. khalayak yang selalu menunggu perkembangan berita terkait permasalahan TKI di Arab Saudi setiap saat. Kelebihan rapid updating SKE menjadi solusi bagi khalayak untuk dapat selalu mengikuti pemberitaan setiap saat.

Sementara sumber berita yang digunakan akan lebih banyak menggunakan sumber berita formal, seperti pejabat Pemerintah.

Pada berita yang mengandung konflik, liputan dimungkinkan menggunakan tipe dua atau tiga sisi. Namun demikian diduga terjadi perbedaan dalam nilai berita dan tipe liputan, karena perbedaan sistem media yang berlaku di Indonesia dan Arab Saudi akan memengaruhi nilai dan tipe liputan.

Untuk membedah teks media, metode analisis isi (content analysis) menjadi pilihan bagi peneliti mengumpulkan dan menganalisis data. Analisis isi (content analysis) adalah suatu teknik penelitian untuk membuat inferensi-inferensi yang dapat ditiru (replicable) dan valid dari teks atau hal lain yang memiliki makna penuh dengan memperhatikan konteks (Krippendorff, 2004: 18). Dalam hal ini replicable terkait realibilitas alat ukur.

Analisis isi secara teknis memfokuskan dan membatasi diri pada arti dari kata manifes dalam pesan atau makna denotatif dengan prosedur yang sistematis, obyektif, dan kuantitatif.

Secara praktis peneliti mengobservasi informasi berita berdasarkan pada codingsheet yang telah diuji validitas dan reliabilitasnya. Uji validitas dalam penelitian ini menggunakan expert judgment dengan diuji oleh ahli di bidang jurnalisme dan teknologi komunikasi. Sementara uji reliabilitas penelitian ini menggunakan dua orang koder dan diuji menggunakan alpha Krippendorff (2004: 
Komparasi Berita Tenaga Kerja Indonesia di Arab Saudi dalam Detikcom dan Sabq.Org 230). Hasil uji reliabilitasnya adalah hasil 0,781430747. Artinya codingsheet dalam penelitian ini telah valid dan reliabel.

Codingsheet itu berisi lima (5) kategori dan pada setiap kategori terdapat tiga (3) hingga sebelas (11) klasifikasi. Kelima kategori itu adalah: 1). Nama Suratkabar dengan kelas frekuensi berita; 2). Format Berita dengan kelas hardnews, softnews dan feature; 3). Sumber Berita dengan kelas formal information chanel, first hand report, enterprise, sumber leak dan kombinasi; 4). Tipe Koverasi dengan klasifikasi one-side coverage dan two or multi coverage; 5). Laporan Peristiwa.

Teknik analisis data dalam penelitian ini dilakukan dengan cara mencermati nilai terbesar dan nilai terkecil data statistik dengan uji distribusi frekuensi. Kemudian akan dilakukan uji beda dengan chi-square. Keduanya dilakukan dengan bantuan SPSS for windows 16.

Temuan peniliti menyatakan bahwa isu TKI di Arab Saudi menjadi sajian yang cukup menarik bagi media, baik dalam negeri maupun luar negeri khususnya di Indonesia dan Arab Saudi. Terbukti ada 131 isi berita tentang TKI di Arab Saudi pada tahun 2011 pada suratkabar online Detikcom dan Sabq.org dengan perincian pada Detikcom terdapat 64 berita dan pada Sabq.go.id terdapat 67 berita. Artinya ada perimbangan berita pada media di Indonesia dan Arab Saudi dalam memberitakan persoalan TKI.

Pada format berita yang dipilih, dari 131 berita 109 atau $83.2 \%$ di antaranya ditampilkan oleh Detikcom dan Sabq.org dalam format hardnews. Hanya 22 berita disajikan dalam format softnews.

Temuan ini setidaknya mengindikasikan dua hal: Pertama, profesionalitas kinerja wartawan. Dalam hal ini, kedua media sama sama cenderung menggunakan wartawan pemula. Sebab pada umumnya liputan berita dengan format ini lebih banyak diserahkan kepada wartawan pemula. Profesionalitas kinerja wartawan juga dapat dipandang dari aspek perbedaan sistem media yang dianut oleh kedua negara yang memang berbeda. Kedua, kedua media menghendaki agar pembaca menganggap isu TKI merupakan isu penting yang harus segera disikapi, khususnya bagi pengguna jasa di Arab Saudi.

Plat form online yang cenderung mementingkan unsur real time di banding kedalaman berita. Sehingga format hardnews sesuai dengan paradigma di dalam pemberitaan secara online. Meskipun demikian temuan menarik didapati dengan perbedaan yang signifikan pada dimensi format berita. Secara statistik ada perbedaan $<0.0$. Perbedaan ini disebabkan hampir semua berita yang diposting Sabq.org menggunakan format hardnews, yaitu 45 berita atau 95.5\% dari 67 berita dalam format hardnews. Sementara Detikcom memosting 45 berita atau $70.3 \%$ dari 64 format hardnews yang disajikan.

Realitas ini mencirikan bahwa media di Indonesia dan Arab Saudi cenderung sama dalam hal profesionalitas kinerja wartawan, meski dalam hal ini profesionalitas kinerja wartawan di Arab Saudi lebih terbatas dimungkinkan 
karena sistem media yang dianut negara kerajaan itu.

Berikutnya pada laporan berita yang disajikan didapati temuan pada perbedaan yang signifikan. Laporan tentang pengadilan (33.6\%) dan kriminalitas $(24.4 \%)$ mendominasi pemberitaan tentang TKI unit analisis judul berita tentang TKI di Arab Saudi. Sementara upaya perlindungan dan penyelamatan TKI hanya $4.6 \%$ dari keseluruhan berita TKI di Arab Saudi.

Temuan menarik lainnya dari Sabq.org adalah berita tentang persoalan trafficking, prostitusi dan TKI ilegal dengan frekuensi 6 berita (4.6\%). Temuan menarik lainnya adalah berita TKI bunuh diri dan TKI melarikan diri dengan frekuensi 15 berita $(11.5 \%)$. Kedua isu itu sama sekali tidak disinggung di dalam pemberitaan Detikcom.

Artinya salah satu ciri media di Arab Saudi adalah dominasi berita kriminalitas dan kelanjutannya, yaitu pengadilan. Sementara media di Indonesia dalam memberitakan lebih didominasi oleh berita perlindungan dan penyelamatan.

Ada sisi kesamaan dari kedua kedua media terkait denga fungsi kontrol sosial, bahwa keduanya hendak melindungi warga negara.

Perbedaan signifikan juga didapati pada unit analisis nilai berita berita sebesar $<0$. Tidak ada perbedaan tipe koverasi pada kedua SKE. Perbedaan signifikan juga didapati pada laporan peristiwa tentang TKI $<0$.

Selanjutnya hasil uji statistik menunjukkan bahwa Lead yang menonjolkan unsur ' what' sebanyak 77 berita atau $58 \%$ mendominisi berita tentang TKI oleh Detikcom dan Sabq.org. sementara lead yang menonjolkan unsur 'bow' sebanyak 8 berita atau $6.1 \%$.

Temuan ini tidak mengherankan bila merujuk temuan sebelumnya terkait dominasi format berita hardnews. Seperti diketahui bahwa format hardnews biasanya dipilih karena menganggap penting sebuah kejadian. Anggapan penting itu biasanya cenderung menekankan unsur "apa" yang terjadi, bukan unsur lain dalam berita, seperti unsur who, when, where, why dan unsur how.

Dari hasil uji beda, tidak ada perbedaan signifikan pada Detikcom dan Sabq.org dalam sama sama menekankan satu unsur di dalam lead berita. Berdasarkan temuan sebelumnya bahwa dapat dinyatakan bahwa format hardnews cenderung menekankan unsur 'what'.

Meski paradigma berita online adalah real time nilai berita timelines tidak mendominasi pemberitaan tentang TKI di Arab Saudi pada Detikcom dan Sabq.org. Hasil uji statistik menunjukkan hanya 24 berita $(18.3 \%)$ penekanan pada ketepatan waktu. Penekanan terjadi pada nilai buman interest sebesar 32 atau 24. $4 \%$ dan nilai Conflict/controversy sebanyak 29 berita atau $22 \%$.

Temuan ini mengindikasikan, bahwa nilai kemanusiaan seperti emosi dan ketegangan pada objek berita yang bukan orang terkenal seperti TKI, cenderung mendominasi pemberitaan konflik dan kontroversi yang terjadi kepadanya. 
Komparasi Berita Tenaga Kerja Indonesia di Arab Saudi dalam Detikcom dan Sabq.Org

Namun demikian, ada perbedaan signifikan $<0.00$ pada unit analisis nilai berita. Perbedaan ini nampak pada nilai berita importance atau tokoh penting di dalam pemberitaan seperti pemerintah kerajaan Arab Saudi tidak didapati satupun ruang pemberitaan isu TKI. Hal ini dimungkinkan keterbatasan pada profesionalisme kinerja wartawan sistem media di Arab Saudi. Para wartawan di Arab Saudi amat berhati hati meliput keluarga Kerajaan.

Temuan penekanan nilai berita itu mendasari hasil pada sumber berita yang dipilih. Hasil uji statistik menunjukkan Detikcom lebih menyukai sumber berita formal information channel atau pemerintah sebesar 54 berita atau $41 \%$. Sementara Sabq.org menyukai sumber berita kombinasi yang terdiri dari sumber berita formal dan saksi sebanyak 32 berita atau $34.4 \%$. Jenis sumber berita first hand report seperti saksi mata hanya memperoleh porsi liputan 7 berita atau $5.3 \%$.

Temuan menarik lainnya dari Sabq.org adalah munculnya sumber berita leak atau anonym, yaitu sebanyak 15 berita atau 22.4\%. ihwal tidak menyebutkan nama sumber dalam tradisi jurnalisme itu sah. Namun jumlah yang cukup besar itu mengindikasikan ada yang berbeda pada praktik jurnalisme dan kode etik jurnalistik di Arab Saudi, yang salah satunya mengenai hak merahasiakan sumber berita.

Temuan ini menginformasikan meski sama sama menyukai sumber berita pemeritah dalam memberitakan persoalan TKI, Sabq.org. lebih variatif dalam memilih sumber berita. Penyebabnya persoalan TKI selalu melibatkan pemerintah terkait kebijakan tenaga kerja, khususnya tenaga kerja di luar negeri. Padahal sumber berita pertama seperti saksi dan TKI itu sendiri dapat menjadi sumber berita yang menarik, mempunyai derajat nilai berita yang tinggi dan dapat meningkatkan akuntanbilitas pemberitaan.

Meski sama sama menyukai sumber berita formal, ada demikian Perbedaan signifikan $<0.00$ pada kedua sumber berita yang dipilih. Perbedaan ini tampak pada munculnya sumber berita kombinasi yang ada pada Sabq.org.

Pemberitaan mengenai konfik dan kontroversi yang mendominasi semestinya disertai dengan teknik peliputan yang mengakomodir dua belah pihak. Namun kenyataanya hasil uji statistic menunjukkan bahwa tipe koverasi one-sided coverage mendominasi pemberitaan TKI di Arab Saudi pada Detikcom dan Sabq.org yaitu sebanyak 114 berita atau $87.0 \%$. Two or multi-sided coverage 17 $13.0 \%$. Hasil uji beda juga menunjukkan tidak ada perbedaan signifikan pada pemberitaan TKI di Arab Saudi oleh Detikcom dan Sabq.org.

Penyebabnya dimungkinkan karena paradigma berita online yang mengharuskan posting berita secara real time dan proses selanjutnya adalah rapid updating atau update berita setiap kali ada perkembangan pada suatu kasus. 


\section{PENUTUP}

Dengan menggunakan analisis isi sebagai metode untuk mengetahui bagaimana media online dominan di Indonesia dan Arab Saudi meliput TKI di Arab Saudi, beberapa catatan penting di dapati.

Pertama, kedua media daring atau online di Indonesia dan Arab Saudi dalam tahun yang sama memposting berita tentang TKI di Arab Saudi dalam frekuensi yang berimbang dengan format hardnews. Realitas ini menandakan bahwa kedua media sadar bahwa isu ini penting bagi khalayak di kedua negara. Karakter isu yang memang cenderung kontroversial seperti isu TKI biasanya memancing media untuk melaksanakan fungsi sebagai kontrol sosial dan memberi semacam alarm bagi semua pihak yang berkepentingan khususnya pengguna jasa bagaimana mereka bersikap.

Kedua, fokus pemberitaan lebih kepada proses pengadilan dan kriminalitas. Hal ini jelas mempengaruhi persepsi khalayak seakan-akan TKI dari Indonesia adalah sumber masalah. Dalam hal ini media seharusnya juga meliput keberhasilan TKI dalam pekerjaan dan kontribusi mereka terhadap kepentingan negara dan warganya.

Ketiga, liputan one-sided coverage mendominasi pemberitaan TKI di Arab Saudi. Padahal persoalan TKI adalah realitas yang rawan konflik dan kontroversi. Sehingga liputan two or multi-sided coverage mutlak harus dilakukan meskipun berita itu menggunakan platform online. Sebab salah satu hak pembaca adalah mendapatkan pemberitaan yang disamping faktual, liputan berimbang juga menjadi sebuah keharusan.

Pada akhirnya, dalam memberitakan isu TKI di Arab Saudi, Detikcom dan Sabq.org sama-sama belum menampilkan realitas yang utuh mengenai kondisi sebenarnya dari TKI di Arab Saudi.

\section{DAFTAR PUSTAKA}

Abrar, A.N. (2005). Penulisan Berita Edisi Kedua, Yogyakarta: Universitas Atmajaya.

Ajeng, C.D. (2014). Penerapan Self Censorship dalam Editorial Pemberitaan Kejahatan Asusila Anak di Media Online (Studi Kasus Pemberitaan Kejahatan Asusila Anak di JIS dalam Situs Berita Detik.com dan Merdeka.com), dalam Jurnal Ilmiah Universitas Bakrie, 2(5).

Akbarian, I.A., Suprihatini, T., Yulianto, M., \& Nugroho, A. (2014). Pembingkaian Berita Media Online : Kasus Kekerasan terhadap Perempuan sebagai Tenaga Kerja Wanita (TKW), dalam Jurnal Interaksi Online Mahasiswa (JOM), 2(8).

Amalia, F.F., \& Rachmawati, R. (2013). Pemanfaatan Teknologi Informasi dan Komunikasi oleh Tenaga Kerja Indonesia serta Pengaruhnya terhadap 
Komparasi Berita Tenaga Kerja Indonesia di Arab Saudi dalam Detikcom dan Sabq.Org

Perubahan Sosial Budaya di Kampung Pandan Dalam, Ampang Jaya, Malaysia, dalam Jurnal Bumi Indonesia, 2(1).

Assegaf, H.D. (1983). Jurnalistik Masa Kini, Jakarta: Ghalia Indonesia.

Astrid, F.A., (2011). Pemberitaan Human Trafficking (Perdagangan Manusia)

Dalam Surat Kabar Elektronik Di Lima Negara Asean Human Trafficking

News On On-Line Media In Five Countries In Asean. Jurnal Kareba, 1(3).

Geriya, S. S. (2002). Profil Tenaga Kerja Wanita Indonesia, dalam Jurnal Studi Jender Srikandi, 2(2).

Gunter, B. (2003). News and The Net, New Jersey: Lawrence Erlbaum Associates Publishers.

Hallin, C., D dan Mancini, P. (2004). Comparing Media Systems. Cambridge: Cambridge University Press

Handayani, W.D. (2011). Studi Analisis Isi Berita dan Opini Surat Kabar Lampung Post tentang Kasus Perdagangan Perempuan dan Anak Kurun Waktu Tabun 2010. Jurnal Lampung: Universitas Lampung 2011.

Hardi, M.N. (2015). Tingkat Kepatutan Berbahasa Jurnalistik Pada Jurnalisme Online Di Situs Detikbandung.Com (Studi Deskriptif Dengan Teknik Analisis Isi Terhadap Penerapan Kaidah Bahasa Jurnalistik Berita Langsung (Straight News) Di Detikbandung.Com) dalam Komunikatif, 4(2).

Hargreaves, I. (2005). Journalism: A Very Short Introduction. New York: Oxford University Press.

Krippendorff, K. (2004). Content Analysis an Introduction to its Metodology $2^{\text {nd }}$ Edition. London: Sage Publiction

Marta, R.F., \& Septyana, V. (2015). Semiotika Pemasaran pada Brand Value melalui Sign berupa Layout Berita dan Iklan Ibadah Haji (Studi Komparasi pada Harian Pos Kota dengan Rakyat Merdeka), dalam Jurnal Semiotika, 9(2).

McKane, A. (2006). News Writing. London: Sage Publiction

McQuail, D. (1992). Media Performance: Mass Communcations and The Public Interest. London: Sage Publication

McQuail, D. (1994). Teori Komunikasi Massa Edisi Kedua. Jakarta: Erlangga

Mulyono, D.C. (2011). Berita Kekerasan Terhadap Anak Pada Surat Kabar Elektronik (SKE). Tesis. Fisipol Universitas Gajah Mada

Nurcahyo, A. (2013). Konstruksi Berita Pelanggaran HAM di Mesuji (Studi Analisis Framming tentang Konstruksi Pemberitaan Pelanggaran HAM di Mesuji pada Harian KOMPAS), dalam Jurnal Flow, 2(2).

Pavlik, V.J. (1996). New Media Technology Curtural and Commercial Perspektives. U.S.A: Allin and Bacon

Prajarto, N. Dkk. (2006). Komparasi Liputan Surat Kabar Kedaulatan Rakyat, Bernas Jogja, Radar Jogja, Kompas dan Merapi Tahun 2006 terhadap Kegiatan di Kabupaten Sleman. Laporan Penelitian. Yogyakarta: Fisipol UGM 
Muhamad Fahrudin Yusuf \& Mukti Ali

Quinn, S. dan Lamble, S. (2008). Online Newssgathering Research and Reporting for Journalism. Oxford: Focal Press.

Rahayu, D. 2008. "Tindakan Perdagangan Perempuan dalam Proses Pengiriman Buruh Migran di Madura" Siti Hariti Sastriani (ed.). Women In Public Sector. Yogyakarta : PSW UGM dan Tiara Wacana

Ramayani, C., Aimon, H., \& Anis, A. (2012). Analisis Produktivitas Tenaga Kerja dan Pertumbuhan Ekonomi Indonesia, dalam Jurnal Kajian Ekonomi, 1(1).

Ramli, R. (2015). Analisis Isi Berita Demonstrasi Bersih 4.0 pada Fajar, Tribun Timur, Sindo. Dalam JPP (Jurnal Politik Profetik), 3(1).

Rich, C. 2010. Writing and Reporting News: A Coaching Method, 6th Edition. Boston: Wadsworth, Cengage Learning

Rubawati, E. (2018). Berita Online Sebagai Instrumen Dakwah: Antara Profetik dan Provokatif Analisis Framing Media Online Serambinews.com dan Panjimas.com Terhadap Pemberitaan LGBT, dalam Jurnal Tasamub: Jurnal Studi Islam, 10(1).

Rugh, W. A. (2004). The Arab Press: News Media and Political Process in The Arab World, Revised 2nd, Syracuse, NY: Syracuse University Press.

Sahayu, W. (2008). "Pemberangkatan TKW: Pemberdayaan atau Memperdaya Wanita" dalam Siti Hariti Sastriani (ed.). Women In Public Sector. Yogyakarta: PSW UGM dan Tiara Wacana

Sakr, N. (2005). "The Changing Dynamics Of Arab Journalism" alam Making Journalist. Hugo De Burgh (ed.). New York: Routledge

Sari, M.F. (2015). Komparasi Nilai Berita Tayangan Infotainment Insert Di Trans Tv Dengan Intens Di RCTI dalam Jumal Visi Komunikasi, 14(2).

Severin, J.W. Jr dan Tankard, J.W. (2009). Teori Komunikasi: Sejarah, Metode, dan Terapan di Dalam Media Massa Edisi Lima. Jakarta: Prenada Media.

Sholeh, M. (2007). Permintaan dan Penawaran Tenaga Kerja serta Upah: Teori serta Beberapa Potretnya di Indonesia, dalam Jurnal Ekonomi dan Pendidikan, 4(1).

Siebert, F. S. (1986). Empat Teori Pers. Jakarta: Penerbit Intermasa.

Sutaat. (2006). Permasalahan Tenaga Kerja Wanita dan Implikasinya terhadap Pelayanan Sosial dalam Jurnal Penelitian dan Pengembangan Kesejateraan Sosial, 11(3).

Sutedi, A. (2009). Hukum Perburuhan. Jakarta: Sinar Grafika.

Syuderajat, F. (2017). Ideologi Surat Kabar dalam Pemberitaan Terorisme. Communicatus: Jurnal Ilmu Komunikasi, 1(1), 1-12.

Utami, L.A. (2017). Analisis Sentimen Opini Publik Berita Kebakaran Hutan melalui Komparasi Algoritma Support Vector Machine dan K-Nearest Neighbor Berbasis Particle Swarm Optimization, dalam Jurnal Pilar Nusa Mandiri, 13(1).

Ward, M. (2002). Journalism Online. Oxford: Focal Press 